\title{
Selkup Language
}

National Cancer Institute

\section{Source}

National Cancer Institute. Selkup Language. NCI Thesaurus. Code C154111.

A Uralic language spoken by the Selkup people of Russia. 